\title{
Z HISTORII
}

DOI: $10.5604 / 01.3001 .0013 .5705$

\section{Mikolaj BrenK}

ORCID: https://orcid.org/0000-0001-6576-7163

\section{Katolicka SzKota SpOteCZna W POZNANIU (1927-1939)}

\section{ABSTRAKT}

Katolicka Szkoła Społeczna w Poznaniu była jednym z czołowych polskich ośrodków dydaktycznych dla służb społecznych w okresie międzywojennym. Prowadziła w latach 1927-1939 kursy oraz studia dla kadr zakładów opiekuńczych i instytucji społecznych, przede wszystkim tych o proweniencji kościelnej. Priorytetem w działalności szkoły było organizowanie, od momentu erygowania placówki w 1927 r., dwuletniego kursu pracy społecznej, z czasem funkcjonującego pod nazwą Wyższego Katolickiego Studium Społecznego. Z kolei w czerwcu 1937 r. szkoła uzyskała prawa państwowe szkoły wyższej i nazwę Wyższego Katolickiego Studium Społecznego. Celem artykułu jest ukazanie wybranych aspektów funkcjonowania placówki, związanych z jej powstaniem oraz działalnością edukacyjno-wychowawczą do 1939 roku. W tym celu dokonano analizy zachowanych materiałów źródłowych w postaci archiwaliów, artykułów zamieszczanych w czasopismach II RP oraz sięgnięto do nielicznych opracowań powstałych po 1945 roku.

Słowa kluczowe: szkoła społeczna, opieka społeczna, służby społeczne, Druga Rzeczpospolita

\section{WSTĘP}

$\mathrm{D}$

ziałająca w latach 1927-1939 Katolicka Szkoła Społeczna w Poznaniu (KSS) była ośrodkiem dydaktycznym, w którym kształcono i dokształcano kadry kościelnych zakładów opiekuńczych i instytucji charytatywnych. Była to pierwsza w Polsce szkoła kościelna kształcąca działaczy społecznych (Banaszak, 1974, s. 82), stąd jej powstanie i działalność miały charakter ponadregionalny, ogólnopolski. Dotychczas szkoła ta nie doczekała się opracowania w formie monografii. Istotnym powodem ta- 
kiego stanu rzeczy jest zniszczenie w okresie II wojny światowej znaczącej części materiału źródłowego pozwalającego odtworzyć dzieje szkoły w sposób całościowy, a spuścizna, która pozostała, ogranicza się do fragmentarycznych danych przechowywanych w dwóch niewielkich zespołach udostępnianych w Archiwum Państwowym w Poznaniu oraz w Archiwum Archidiecezjalnym w Poznaniu ${ }^{1)}$. Ponadto wydawane przez szkołę czasopismo „Przegląd Społeczny”, które mogłoby być źródłem wiedzy o jej bieżącym funkcjonowaniu, nie zwykło zamieszczać na swoich łamach obszerniejszych sprawozdań ${ }^{2}$. Celem prezentowanego artykułu jest przybliżenie genezy, ram organizacyjnych oraz wybranych aspektów funkcjonowania placówki. Materiał źródłowy opracowania stanowią wspomniane archiwalia, uzupełnione o notatki i artykuły z czasopism z okresu funkcjonowania szkoły oraz nieliczne późniejsze publikacje. Niniejsza praca ma charakter przyczynku do dalszych badań, stąd wybiórczo traktuje kwestie już podjęte w opracowaniach (m.in. genezę powstania KSS, sytuację społeczną Wielkopolski, główne problemy społeczne po zakończeniu wojny oraz kwestie organizowania kursów dla wychowawczyń KSS, zob. Banaszak, 1974; Piaszyk, 1979), a także sylwetki wielu wybitnych postaci, które brały udział w powstawaniu i funkcjonowaniu placówki.

\section{Geneza I powstanie Katolickiej Szkoty SpoteCZnej}

Po odzyskaniu przez Polskę niepodległości w 1918 r. w środowisku działaczy społecznych Poznania pojawiła się potrzeba utworzenia placówki kształcącej pracowników szeroko rozumianych katolickich instytucji społecznych. Wpisywało się to niewątpliwie w rozwój katolickiej myśli społecznej w okresie dwudziestolecia międzywojennego, o którym Janina Kostkiewicz (2013, s. 455-456) pisze: „Jest on wynikiem świadomego

1) Zespół Katolicka Szkoła Społeczna w Poznaniu przechowywany w Archiwum Państwowym w Poznaniu składa się z 21 niewielkich objętościowo jednostek, natomiast zespół o tej samej nazwie udostępniany przez Archiwum Archidiecezjalne w Poznaniu zawiera 30 jednostek.

2) Wyjątkiem jest sprawozdanie zamieszczone w pierwszym numerze „Przewodnika Społecznego" z 1930 roku. 
działania zarówno hierarchów i duchownych Kościoła katolickiego, jak i pewnej, związanej z nim grupy inteligencji świeckiej. Zaczyna się rozwijać nowa dziedzina wiedzy: katolicka nauka społeczna. [...] jej rozwój był inspirowany przez co najmniej dwa główne źródła. Pierwsze ma dwa wymiary: działanie papieża Piusa XI, który inicjując Akcję Katolicką w Kościele powszechnym (we wszystkich krajach europejskich), dał odpowiedź rosnącym w siłę totalitaryzmom: komunizmowi, włoskiemu faszyzmowi, narodowemu socjalizmowi Niemiec, rozwój filozoficznej myśli personalistycznej w Europie. Drugim źródłem - i jak się wydaje na gruncie polskim odgrywającym większą rolę niż inspiracje zewnętrzne - była sytuacja polityczna (odzyskanie niepodległości po półtorawiekowej niewoli) i tragiczna, wynikająca ze zniewolenia i wyniszczenia narodu, sytuacja ekonomiczno-gospodarcza, moralna, kulturalna połączona z nieustającym zagrożeniem ponowną utratą niepodległości”. Warto podkreślić, że istotnym wymiarem katolickiej nauki społecznej było wychowanie społeczne kierowane głównie do dorosłych Polaków przynależących do Kościoła katolickiego (Kostkiewicz, 2015, s. 30). Tenże wymiar wychowawczy katolickiej nauki społecznej w pełni realizowała Katolicka Szkoła Społeczna w Poznaniu, a jej dyrektor ks. Eugeniusz Kozłowski był jednym z czołowych reprezentantów tego nurtu w Polsce międzywojennej (Jarocki, 1964, s. 261-262).

Dobry grunt do powstania Katolickiej Szkoły Społecznej zapewniły podejmowane w tym czasie w Poznaniu inicjatywy związane z organizowaniem krótkoterminowych kursów i szkoleń o profilu społecznym, bądź o profilu ogólnoświatowym z uwzględnieniem treści z zakresu nauk społecznych. Przykładem są tu kursy dla robotników miasta Poznania z października 1918 r., kurs pracy zarządowej zorganizowany przez ks. Waleriana Adamskiego we wrześniu i październiku 1920 r. dla Związku Stowarzyszeń Młodzieży Polskiej, czy I Zjazd Delegowanych i Kurs Związku Stowarzyszeń Polskiej Młodzieży Żeńskiej z października 1920 r. (Banaszak, 1974, s. 85-86).

Pewną mobilizacją do utworzenia szkoły o profilu katolickim była także działalność na polu szkoleniowym dla pracowników społecznych instytucji świeckich, m.in. Wolnej Wszechnicy Polskiej w Warszawie oraz organizowane przez Związki Zawodowe kursy akcji społecznej (tamże, s. 90). 
Argumentując potrzebę powołania szkoły społecznej, a także kreśląc profil jej działalności, pisał przyszły dyrektor ks. Eugeniusz Kozłowski (1922, s. 39) na łamach „Przewodnika Społecznego” w 1922 r.: „Chcąc osiągnąć trwalsze i znamienniejsze rezultaty, nie możemy się obyć bez specjalnej szkoły społecznej. Szkoła taka miałaby bardzo rozległy zakres działalności. Będąc czynna przez cały rok, urządzałaby kursy, dostosowane w planie swym do potrzeb poszczególnych organizacyj. Musiałyby więc być osobne wykłady dla członków zrzeszeń robotniczych, kobiecych, młodzieży itd. Celem takich mniej więcej 6 tygodni do 2 miesięcy trwających kursów, byłoby danie uczestnikom ogólnego wykształcenia społecznego [...]”.

Wśród czynników, które w ciągu kilku lat przyczyniły się do otwarcia szkoły decydujący wpływ miała działalność osób, które zwykło się określać terminem „społecznik ${ }^{3) ” ~-~ g r u p a ~ d o b r z e ~ z o r g a n i z o w a n y c h ~ i ~ z a a n g a z ̇ o w a-~}$ nych w tworzenie nowego ośrodka kształceniowego działaczy, głównie kapłanów pracujących aktywnie w wielkopolskich stowarzyszeniach. Wśród nich należałoby wymienić prymasa Polski kardynała Edmunda Dalbora, który w 1923 r. powołał fundusz społeczny zbierający środki materialne na rzecz budowy szkoły, a w 1924 przekazał dom przy ul. Podgórnej 12b w Poznaniu - przyszłą siedzibę placówki (Bender, 2000, ł. 1088). Niewątpliwy wkład w powstanie koncepcji szkoły mieli księża społecznicy tworzący Komitet Organizacyjny Katolickiej Szkoły Społecznej w Poznaniu, będący liderami wielkopolskich organizacji: ks. Czesław Michałowicz ze Związku Katolickich Towarzystw Robotników Polskich, ks. Tadeusz Zamysłowski ze związku kapłanów „Unitas”, ks. Franciszek Forecki ze Związku Kobiet pracujących, ks. Walenty Dymek ze związku Towarzystw Dobroczynności „Caritas”, ks. Ludwik Janosz ze Związku Młodzieży Polskiej, ks. Walerian Adamski - dyrektor Zjednoczenia Młodzieży Polskiej, ks. Józef Szulc ze Związku Młodych Polek i ks. Józef Prądzyński z Ligi Katolickiej. Do tego grona należałoby dodać z pewnością ks. Eugeniusza Kozłowskiego, przez cały czas istnienia KSS pełniącego funkcję jej dyrektora, który był w ówczesnej Wielkopolsce największym autorytetem z zakresu nauki społecznej

3) Termin społecznik przyjmuję za tzw. słownikiem warszawskim tj. Stownikiem języka polskiego (1909, s. 315): „działacz społeczny, ten co bierze udział w ruchu społecznym”. 
Kościoła, choć po doktoracie zrezygnował z pracy stricte naukowej na rzecz rozległej działalności społecznej (Banaszak 1983d, s. 190)4). Zarówno kwestia wymienionych, jak i pozostałych społeczników zaangażowanych w powstanie i działalność szkoły, a także osoba (i osobowość) ks. Kozłowskiego mogłyby stanowić temat dalszych analiz z racji obszerności zagadnienia.

Otwarcie szkoły zaplanowano na rok 1926 i temu zamierzeniu podporządkowano prace organizacyjne remontowe w budynku przy ul. Podgórnej. Jednakże śmierć kardynała Dalbora w lutym 1926 r. i przedłużający się wakat na stolicy arcybiskupiej do 2 października spowodował konieczność odroczenia uroczystości otwarcia szkoły o pełen rok akademicki (Banaszak, 1974, s. 91). Katolicka Szkoła Społeczna została erygowana w Poznaniu w dniu 13 czerwca 1927 r. mocą rozporządzenia Arcybiskupa Gnieźnieńskiego i Poznańskiego kardynała Augusta Hlonda, Prymasa Polski. Pierwszym dyrektorem szkoły został mianowany wspomniany ks. dr Edward Kozłowski. Uzasadniając potrzebę zaistnienia nowej placówki, prymas wskazywał na konieczność kształcenia społeczników według wzoru nakreślonego w dokumentach papieża Leona XIII5), brak tego rodzaju instytucji w Polsce oraz przykład innych narodów katolickich w tym zakresie $^{6}$. Jako osoby i instytucje, które bezpośrednio przyczyniły się do otwarcia szkoły, prymas wymienił swojego poprzednika kardynała Dalbora, Drukarnię i Księgarnię św. Wojciecha oraz Komitet Organizacyjny złożony ze wspomnianych kierowników istniejących w diecezji gnieźnieńskiej i poznańskiej katolickich związków i stowarzyszeń (Rozporządzenie, 1927, s. 32). Baza lokalowa i dydaktyczna szkoły została w ciągu kilku lat odpowiednio przygotowana, a stanowił ją zakupiony w tym celu trzy lata wcześniej dom przy ul. Podgórnej 12b w Poznaniu, doposażone sale szkol-

4) Biogramy ks. E. Kozłowskiego opracowali także L. Kula, 1994 oraz J. Jachowski, 1970.

5) Programowym pismem Leona XIII w zakresie myśli społecznej była encyklika Rerum novarum ogłoszona 15 maja 1891 roku.

6) Warto dodać, że podobne, tj. katolickie szkoły kształcące pracowników społecznych, istniały w tym czasie w Belgii (w Brukseli i Lowanium), we Francji (kilka szkół), w Amsterdamie, cztery w Niemczech (Monachium, Aachen, Paderborn, Berlin), dwie w Stanach Zjednoczonych (Waszyngton, Chicago) w Szwajcarii (Fryburg). Za: Banaszak, 1974, s. 82-83; Rozporządzenie..., 1927, s. 32. 
ne, biblioteka wraz ze zbiorem literatury społecznej. Przychody nowo powołanej instytucji miały stanowić m.in. wpływy z prowadzenia czasopisma „Przewodnik Społeczny” oraz dofinansowanie ze wspomnianej Drukarni i Księgarni św. Wojciecha (tamże).

Określone w statucie cel i zadania Katolickiej Szkoły Społecznej zawierały się w pięciu punktach:

„1) szerzenie i pogłębianie katolickich zasad społecznych oraz metod działania społecznego;

2) przygotowanie kierowników i współpracowników społecznej akcji katolickiej;

3) popieranie katolickiego ruchu naukowego w tej dziedzinie;

4) utrzymanie biblioteki społecznej;

5) wydawanie czasopism i innych wydawnictw z dziedziny społecznej" (Statut, 1927, art. 3).

Szkoła była odrębną instytucją diecezjalną archidiecezji poznańskiej, posiadającą osobowość prawną. Podlegała Arcybiskupowi Gnieźnieńskiemu i Poznańskiemu, który mianował i odwoływał dyrektora, miał we władzach szkolnych swojego delegata, posiadał głos ostateczny w rozstrzyganiu decyzji dotyczących placówki oraz mógł unieważnić zarządzenia organów szkoły. Zarząd nowo powołanej placówki stanowiło Kuratorium szkoły, w skład którego wchodzili kierownicy wspomnianych organizacji założycielskich, przedstawiciele innych katolickich organizacji katolickich statutowo podporządkowanych Arcybiskupowi Gnieźnieńskiemu i Poznańskiemu lub Prymasowi Polski, inne osoby mianowane przez arcybiskupa. Zadaniem Kuratorium było m.in. czuwanie nad kierunkiem i działalnością KSS, uchwalanie regulaminów i instrukcji; przedkładanie arcybiskupowi kandydatów na dyrektora, jego zastępców oraz etatowych profesorów szkolnych; zatwierdzanie budżetu szkolnego oraz rocznych sprawozdań naukowych i administracyjnych (tamże, 1927, art. 5-9). Katolicka Szkoła Społeczna posiadała uprawnienia państwowe, tzn. działała na podstawie obowiązujących rozporządzeń ministerialnych ${ }^{7}$.

7) Zakresie kształcenia pracowników systemu opieki społecznej regulowały m.in. następujące akty prawne: Rozporządzenie Ministra Pracy i Opieki Społecznej z dnia 10 


\section{DZIAŁALNOŚĆ DYDAKTYCZNA KSS}

Działalność dydaktyczna szkoły została zapoczątkowana jeszcze przed jej erygowaniem, tj. we wrześniu 1926 r. pod egidą Komitetu Organizacyjnego Szkoły Społecznej. Od tamtej pory były organizowane dwa rodzaje kursów: krótkoterminowe, przybierające różną formę organizacyjną i merytoryczną, oraz dwuletni kurs pracy społecznej będący priorytetem w zakresie działalności dydaktycznej szkoły. Pewną systematykę oferty kształceniowej KSS oddaje sprawozdanie KSS za rok 1928, które uzupełnione o informacje z innych źródeł pozwala omówić rodzaje prowadzonych kursów oraz grupy odbiorców, do których je kierowano. Niestety zachowane materiały nie pozwalają zestawić wszystkich kursów i szkoleń z całego okresu działalności szkoły, stąd zostaną one zaprezentowane drogą egzemplikacji.

Kursy krótkoterminowe KSS przyjmowały dwie zasadnicze formy: specjalistyczną - zajęć dla określonych grup zawodowych pracowników instytucji społecznych (w tym zakładów opiekuńczych) oraz ogólną - tj. wykładów popularyzujących idee katolickiej akcji społecznej (Sprawozdanie, 1930, s. 3).

Pierwszy kurs specjalistyczny, dedykowany wychowawczyniom i wychowawcom zakładów zamkniętych, rozpoczęto już na kilka miesięcy przed formalnym erygowaniem szkoły, tj. 21 września 1926 roku. Organizowano go we współudziale poznańskiego Związku Towarzystw Dobroczynności "Caritas"8). Był on odpowiedzią na powszechny brak wykwalifikowanej kadry w zakładach opiekuńczych dla dzieci wobec ogromnego problemu sieroctwa, jaki wystąpił po zakończeniu działań wojennych i repatriacyjnych (Brenk, Chaczko, Pląsek, 2018, s. 20). Potrzeba tego rodzaju szkoleń zrodziła siedem edycji podobnych kursów organizowanych w KSS w latach 1931-193799. Kurs nazwano dwumiesięcznym, zajęcia jednak kończyły się

października 1927 r. o kwalifikacjach kierowników zakładów opiekuńczych, Dz.U. 1927 nr 100 poz. 866; Rozporządzenie Ministra Opieki Społecznej z dnia 12 września 1932 r. w sprawie zmiany w rozporządzeniu z dnia 10 października 1927 r. o kwalifikacjach kierowników zakładów opiekuńczych, Dz.U. 1932 nr 87, poz. 743.

8) Pierwsza część kursu odbyła się w dn. 21 września 1926 r. - 19 października 1926 r., druga trwała od 3 listopada do 3 grudnia 1927 r. Za: Pismo Dyrekcji..., 1927, k. 4.

9) Szerzej na ten temat pisała Piaszyk, 1979, s. 87 i n. 
dopiero po okresie roku - były podzielone na miesięczny kurs wstępny, samodzielną dalszą praktykę we własnej placówce, kolejny miesięczny kurs końcowy oraz egzamin ${ }^{10)}$. Program kursu wstępnego obejmował ogólne wiadomości z zakresu opieki społecznej, historię wychowania, zasady higieny i wychowania fizycznego, fizjologię i psychologię dziecka, psychologię dziecięcą, zagadnienia przestępczości dziecięcej, organizację wychowania zakładowego, zagadnienia kontaktu z dziećmi po opuszczeniu zakładu, prawa dziecka, kwestie religijne w zakładach, zajęcia pozaszkolne, aktualne zagadnienia pracy charytatywnej (Kurs..., 1926, s. 170). Po kursie wstępnym słuchacze wracali do swoich rodzimych placówek i mieli za zadanie zredagować dwie prace pisemne: streszczenie książki lub artykułu z pedagogiki oraz pracę uwzględniającą własne bieżące doświadczenia zawodowe. Kurs końcowy oprócz wykładów zakładał odwiedziny w zakładach wychowawczych o różnym profilu działalności ${ }^{11)}$ oraz zajęcia praktyczne. Warto zaznaczyć, że dla tego prowadzonego jeszcze w fazie uruchamiania szkoły kursu udało się uzyskać odpowiednie zgody i potwierdzenie ze strony Ministerstwa Pracy i Opieki Społecznej, w którym czytamy, iż „zgadza się na uznanie Kursów dla Wychowawców, prowadzonych przez Katolicką Szkołę Społeczną, za dostatecznie przygotowujące słuchaczów do sprawowania obowiązków wychowawczych w zakładach opiekuńczo-wychowawczych dla dzieci opuszczonych [...]" (Pismo Ministerstwa..., 1927, k. 49). Przy uznaniu kursów ministerstwo postawiło określone warunki. Chodziło m.in. o ujednolicenie nazw przedmiotów i treści innych dokumentów z tymi obowiązującymi już w szkołach społecznych w Warszawie, określenie minimalnego wykształcenia i praktyki słuchaczy jako ukończe-

10) O zaletach dwuseryjności kursów Maria Piaszyk (1979, s. 95) pisała w następujący sposób: „Dwuseryjność stanowiła zasadniczą różnicę pomiędzy kursami KSS a kursami prowadzonymi przez inne ośrodki. Przerwa pomiędzy wykładami obu serii miała doniosłe znaczenie. Wychowawczynie miały bowiem możność skonfrontowania teorii z praktyką oraz wypowiedzenia swoich uwag i spostrzeżeń na ten temat po przybyciu na drugą serię kursu. Miało to zapewne również pewien wpływ na dalsze kształtowanie się programów kursów”.

11) W przypadku pierwszego kursu był to zakład wychowawczy dla dzieci w Szamotułach oraz zakład dla ociemniałych dzieci i miejski zakład wychowawczy dla dzieci w Bydgoszczy. Za: Sprawozdanie..., 1927, k. 15. 
nie siedmioletniej szkoły powszechnej oraz dwuletni staż pracy w zakładzie opiekuńczym. Ponadto na świadectwie ukończenia szkoły miał znajdować się podpis delegata Ministerstwa Pracy i Opieki Społecznej, występującego w charakterze członka komisji egzaminacyjnej z głosem decydującym (Pismo Ministerstwa..., 1927, k. 49-50).

Wspomniany kurs był przygotowywany bardzo starannie. Stąd np. w przypadku wykładowców zakładano, że będą to osoby cieszące się autorytetem w kwestiach społecznych, jak np. Józef Czesław Babicki, Franciszek Harazim SDB, Karol Gustaw Jonscher, Matka Urszula Ledóchowska, prezes Sądu Najwyższego Aleksander Mogilnicki, Wanda Szuman ${ }^{12)}$ (Kurs, 1926, s. 170). Ostatecznie nie wszystkie te osoby prowadziły zajęcia, jednak poszukiwanie dydaktyków wśród wybitnych przedstawicieli nauki i praktyki opieki nad dzieckiem świadczy o dążeniu dyrektora Katolickiej Szkoły Społecznej do wysokich standardów kształceniowych. Warto tu wskazać, że chęć nadania szkole prestiżu poprzez odpowiedni dobór kadr mogła wynikać z podobnych wzorców obowiązujących na kursach dokształcających organizowanych w Warszawie dla wychowawców zakładów opiekuńczo-wychowawczych przez Wydział Opieki nad Dziećmi i Młodzieżą Departamentu Opieki Społecznej. Otóż wśród wykładowców kursów warszawskich znajdziemy m.in. takie postaci jak: Janusz Korczak, Helena Orsza-Radlińska, czy wspomniany Babicki (Program wykładów..., 1926, k. 1). Także stosunkowo duża liczba osób, które nie zdały końcowego egzaminu tj. pięć spośród 25, świadczyć może o chęci stawiania kursantom wysokich wymagań (Notatka prasowa..., 1927, k. 52).

Zachowane materiały wspominają o jeszcze jednym kursie odbywającym się przed formalnym erygowaniem szkoły. Zorganizował go Komitet Organizacyjny Szkoły Społecznej wraz z poznańskim „Caritas” w dniach 8 marca-8 kwietnia 1927 r. dla kierowniczek ochron. Był przeznaczony jako forma dokształcająca dla osób pracujących w ochronkach dla dzieci przedszkolnych lub osób, które choć nie pracują, mają odpowiednie przy-

12) Wanda Szuman od 1933 r. była kierowniczką kursów przygotowujących wychowawczynie do opieki nad dzieckiem (działających w ramach KSS). Na ten temat nie zachował się materiał źródłowy pozwalający dokładniej opisać ten okres jej życia. Zob. Wałęga, 2005, s. 73; 2004, s. 138; Leśniewska, 2009, s. 22-23. 
gotowanie zawodowe (Sprawozdanie, 1930, s. 5). Kurs okazał się niezwykle trafioną propozycją dla doskonalenia warsztatu pedagogicznego, stąd w wyniku licznych próśb zorganizowano go ponownie między 17 kwietnia a 16 maja 1928 r. dla 49 uczestniczek (w tym 23 zakonnic $^{13)}$ ) z Poznańskiego, Pomorza, Śląska, b. Kongresówki i Gdańska. Kierowniczką kursu została znana działaczka oświatowa z Poznania Stefania Marciszewska-Posadzowa (Samsel, 2003, s. 518), a o uznaniu dla działalności szkoły mogła świadczyć uroczysta oprawa uroczystości wieńczącej zajęcia dydaktyczne w dniu 16 kwietnia, w której uczestniczył prymas, duchowni, władze państwowe i samorządowe (Sprawozdanie, 1930, s. 5).

Z kolei drugi chronologicznie kurs krótkoterminowy, już w działającej Katolickiej Szkole Społecznej, odbywał się w dniach 11-23 grudnia 1927 r., i był przeznaczony dla kierowników organizacji robotniczych. Szkoła zorganizowała go wspólnie z Sekretariatem Jeneralnym Związku Katolickich Towarzystw Robotników Polskich w Poznaniu (tamże, 1930, s. 1). W 1928 r. odbyły się jeszcze dwa kursy. W dniach 17-18 marca z inicjatywy Sekretariatu Jeneralnego Związku Kobiet Pracujących w Poznaniu zorganizowano kurs dla członków Towarzystw Kobiet Pracujących, w których wzięło udział aż 145 uczestniczek. Z kolei od 20 do 23 marca trwał kurs pracy charytatywnej zorganizowany przy współudziale poznańskiego „Caritas”. Wzięło w nim udział 36 osób - dziewięciu księży oraz panie z konferencji św. Wincentego à Paulo, pochodzących z różnych regionów Polski: z Poznańskiego, Pomorza, Śląska, Wilna, Warszawy i woj. łódzkiego (Sprawozdanie, 1930, s. 4-5).

Z kolei przykładem kursu ogólnego jest wieczorny kurs społeczny dla pañ ${ }^{14)}$, wzorowany na działalności Katolickiej Szkoły Społecznej w Wiedniu. Jego cele określono w następujący sposób: „wzbudzić należyte zainteresowanie wśród kobiet inteligentnych dla katolickiej akcji społecznej, zapoznać je z głownemi zasadami katolickiej nauki społecznej i wyjaśnić im szereg problemów, kobietę szczególnie obchodzących”. Natomiast potrzebę

13) O znaczącej liczbie sióstr zakonnych wśród studentów KSS pisała Piaszyk, 1979.

14) W roku 1928 kurs ten był zorganizowany w dwóch cyklach, tj. od 28 lutego do 30 marca i od 17 kwietnia do 25 maja. 
kursu dla takiej grupy docelowej uzasadniano silnym wsparciem ze strony kobiet we wszelkiego rodzaju akcjach społecznych i charytatywnych. Organizacyjnie miał on charakter wykładów wieczorowych we wtorki i piątki między godziną 20 a 22 i być może z racji późnej pory nie cieszył się dużym zainteresowaniem. Jednakże merytorycznie był starannie przygotowany, a poszczególne zagadnienia prezentowali prelegenci z doświadczeniem akademickim lub wysokimi kompetencjami zawodowymi. Wśród tematów wykładów znajdowały się: katolicka nauka społeczna, apostolstwo kobiety polskiej, kobieta i małżeństwo w prawie kanonicznym, udział kobiety w życiu charytatywnym, stanowisko kobiety w prawie cywilnym, konflikty we współczesnej rodzinie, prądy ideowe w ruchu kobiecym, nauka o dziecku i młodzieży, udział kobiety w życiu społecznym, państwowa ochrona kobiety, kobieta jako czynnik kultury, kwestia higieny domowej (tamże, 1930, s. 3-4).

Opisane tu kursy stanowią jedynie egzemplifikację działalności szkoły w tym zakresie. Słabo zachowane dokumenty z kolejnych lat działalności szkoły nie pozwalają na ukazanie szczegółowych danych, niemniej jednak fragmentaryczne informacje potwierdzają regularność w organizowaniu specjalistycznych kursów krótkoterminowych, współudział innych organizacji w ich przeprowadzaniu, a także urozmaicony i dobrany pod kątem uczestników program.

Kolejną kwestią wartą omówienia jest zaplecze szkolne. Niestety zachowane na ten temat materiały zawierają niewiele informacji. Placówka przez cały okres działalności mieściła się w Poznaniu przy ul. Podgórnej 12b. Od samego początku istniała w szkole biblioteka, której częścią była czytelnia. Funkcjonowała ona w Poznaniu już wcześniej jako Biblioteka Społeczna Drukarni i Księgarni św. Wojciecha, a następnie została w 1925 r. podarowana na rzecz tworzącej się szkoły społecznej. Wówczas jej księgozbiór składał się jedynie z wydawnictw sprzed I wojny światowej, liczył około 210 publikacji nieperiodycznych oraz 139 numerów periodyków. Już w pierwszym roku działalności (tj. do końca 1928 r.) znacząco powiększono zaplecze naukowe biblioteki, rozszerzając zbiór do 2505 tytułów książek, ponadto prenumerując dziewięć czasopism oraz kilkanaście otrzymując w drodze wymiany wydawanego w szkole „Przewodnika Społecznego” (tamże, 1930, 
s. 8). Maria Piaszyk (1979, s. 96) podaje ponadto, że w szkole mieścił się pokój konsultacyjny, gdzie słuchacze mogli się umawiać na rozmowy i konsultacje z kadrą: „miało to zapewne dodatni wpływ zarówno na uczestniczki, jak i na organizatorów kursu. Pozwalało bowiem organizatorom dostosowywać wykłady i zajęcia kursów do potrzeb uczestniczek”. W sprawozdaniu z początkowego okresu działalności szkoły jest także mowa o internacie, zapewne istniejącym przez cały okres funkcjonowania placówki, który w dwóch salach wieloosobowych mieścił 20 łóżek i służył uczestnikom kursów krótkoterminowych (Sprawozdanie, 1930, s. 7).

\section{DWULETNI KURS PRACY SPOŁECZNEJ}

Priorytetem w działalności Katolickiej Szkoły Społecznej było prowadzenie od momentu erygowania placówki w 1927 r. dwuletniego kursu pracy społecznej, z czasem funkcjonującego pod nazwą Studjum Społecznego Katolickiej Szkoły Społecznej ${ }^{15)}$, a od 1935 r. jako Wyższe Katolickie Studium Społeczne. Władze szkoły od początku dążyły, by kurs „postawić na możliwie wysokiej wyżynie i dostosować go do poziomu podobnych najlepszych instytucyj w kraju i zagranicą" (tamże, 1930, s. 6). Program szkoły opracował dyrektor ks. Edward Kozłowski wraz z księżmi: Walentym Dymkiem, Ludwikiem Jaroszem i Józefem Schulzem ${ }^{16)}$, a jego założenia charakteryzowano w następujący sposób „Specjalny nacisk kładzie na duchowe urabianie słu-

15) Nazwa ta pojawia się w grudniu 1933 r. w tytule II Zjazdu Absolwentów Studjum Społecznego Katolickiej Szkoły Społecznej w Poznaniu, stąd można przyjąć iż używano ją od rozpoczętego dwa miesiące wcześniej nowego roku akademickiego, za: Drugi zjazd..., 1934, s. 1.

16) Ks. Walenty Dymek (1888-1956) przed przyjęciem w 1929 r. godności biskupiej był działaczem społecznym, pełnił m.in. funkcję sekretarza generalnego Caritas, w KSS był członkiem Kuratorium. Z kolei ks. Ludwik Jarosz (1888-1935) był m.in. sekretarzem generalnym Związku Katolickich Stowarzyszeń Młodzieży Polskiej oraz organizatorem w Poznaniu Archidiecezjalnego Instytutu Akcji Katolickiej w Poznaniu, w KSS był prezesem Kuratorium. Natomiast ks. Józef Walenty Schulz (1884-1940) był sekretarzem generalnym Katolickiego Związku Kobiet, redaktorem wydawanego w Poznaniu dwutygodnika poświęconego sprawom kobiet pracujących „Gazeta dla Kobiet” (za: Banaszak, 1983a, s. 338; Banaszak, 1983b, s. 584; Banaszak, 1983c, s. 91-92; Gajewski, 1994, s. 122-123; Odziemkowski, 1994, s. 189). 
chaczy, by wychować dla pracy społecznej w przeróżnych jej dziedzinach nie tylko teoretycznie wykształcone i technicznie biegłe siły, ale także ludzi o głębokiej kulturze religijnej i moralnej. Temu celowi służą tygodniowe egzorty, rekolekcje i specjalne wykłady o posłannictwie pracownika społecznego. $\mathrm{Z}$ dwóch lat zaś studyj jest 6 miesięcy za wzorem belgijskim przeznaczonych na praktyczne szkolenie" (Sprawozdanie, 1930, s. 6).

W kolejnych latach starano się podnosić prestiż studium. Już w lipcu 1933 r. pisano o nim w krótkiej notatce prasowej ${ }^{17)}$, iż ma charakter szkoły wyższej, oraz że „nieliczni zaś kandydaci znajdują wstęp na to Studjum, gdyż ma ono być szkołą elity. Młodzież jednak, która po ukończeniu pełnej szkoły średniej szuka uczelni, która by jej idealizmowi dała jak najtroskliwszą opiekę, a zarazem do zawodu przygotowała znajduje w Katolickiej Szkole Społecznej odpowiednie dla siebie warunki [...]” (Katolicka..., 1933, s. 10). Jak widać, już po pięciu latach działalności szkole nadano cechy uczelni wyższej, co potwierdzono dwa lata później, gdy w 1935 r. dodano człon "Wyższe” do dotychczas funkcjonującego Katolickiego Studium Społecznego ${ }^{18)}$. Z kolei w czerwcu 1937 r. szkoła uzyskała prawa państwowe szkół wyższych ${ }^{19)}$. Dało to możliwość uzyskania prestiżowego dyplomu zarówno kolejnym rocznikom studentów, jak i absolwentom, którzy mogli złożyć egzamin uzupełniający uprawniający do legitymowania się wykształceniem wyższym (Relacja..., 1974).

Szkoła zakończyła działalność po wybuchu wojny we wrześniu 1939 roku. Jednakże jeszcze w okresie wakacyjnym poprzedzającym ten moment ukazywały się w prasie ogłoszenia zachęcające do zapisów osoby,

17) Sądząc po informacjach w prasie międzywojennej, głównie wydawanej przez instytucje Kościoła, informacje o KSS były rozsyłane po całej Polsce i stanowiły dla redaktorów źródło do sporządzenia krótkich notatek prasowych, zakończonych podaniem dokładnego adresu szkoły i informacją o możliwości otrzymania prospektu drogą pocztową. Taka notatka wraz z pismem przewodnim do czasopism, sporządzona przez dyrektora ks. Kozłowskiego, zachowała się w materiałach (Notatka prasowa..., 1927, k. 51-52).

18) W tym czasie Wyższe Katolickie Studium Społeczne ukończył m.in. Józef Burszta, późniejszy dziekan Wydziału Historycznego UAM (1962-1964) oraz prorektor UAM (1965-1968) (za: Jasiewicz, 1988, s. 6).

19) Szkoła miała status szkoły wyższej nieakademickiej, tj. nie miała prawa nadawania akademickich stopni naukowych zgodnie z Ustawą (1937). 
które posiadają świadectwa dojrzałości. Nowy rok szkolny na Wyższym Katolickim Studium Społecznym miał się rozpocząć 3 października 1939 r. (Wyższe... a, 1939, s. 90; Wyższe... b, 1939, s. 247).

\section{ZAKOŃCZENIE}

Tytułem podsumowania należy wskazać, że w okresie międzywojennym Poznań mógł poszczycić się szkołą społeczną kształcącą na wysokim, akademickim poziomie katolickich ${ }^{20)}$ działaczy społecznych oraz pracowników zakładów opiekuńczych. Placówka była prowadzona przez osoby mające doświadczenie w pracy w organizacjach społecznych, a także uchodzące za autorytety w zakresie katolickiej nauki społecznej, której postulaty stanowiły trzon działalności ideologicznej szkoły. Niezwykła dbałość o poziom wykładów, wymagania stawiane na egzaminach i dobór kadr sprawił, że szkoła w kolejnych latach osiągnęła status szkoły wyższej.

\section{BiBLIOGRAFIA}

\section{Materiały archiwalne}

Pismo Dyrekcji Katolickiej Szkoły Społecznej w Poznaniu do Urzędu Wojewódzkiego w Poznaniu w sprawie uznania kursów dla wychowawców [listopad 1927]. Archiwum Państwowe w Poznaniu (dalej APP), zespół Katolicka Szkoła Społeczna (dalej KSS), sygn. 1. k. 4.

Pismo Ministerstwa Pracy i Opieki Społecznej do Urzędu Wojewódzkiego w Poznaniu w sprawie uznania kursów dla wychowawców. Warszawa, dn. 28 listopada 1927 r. APP, KSS, sygn. 1, k. 49-51.

Program wykładów na Kursach Dokształcających zorganizowanych przez Wydział Opieki nad Dziećmi i Młodzieżą Departamentu Opieki Społecznej dla wychowawców zakładów opiekuńczo-wychowawczych [1926]. APP, KSS, sygn. 2, k. 1-4.

20) Dane z roku akademickiego 1937/1938 (Wysocki, 2007, s. 119) wskazują, że na 97 studentów szkoły wszyscy byli wyznania rzymskokatolickiego. Wydaje się, iż taka sytuacja była pożądana przez dyrekcję szkoły, jednoznacznie wskazującą na ideał wychowawczy proponowany przez katolicką myśl społeczną tego okresu. Toteż w wysyłanych do czasopism informacjach dotyczących profilu szkoły czytamy m.in., że jej celem jest „wysyłać w życie młodzież zapatrzoną w katolickie ideały społeczne” (Studjum..., 1933, s. 191). Podobne sformułowanie zostało użyte w: Studjum..., 1932, s. 71. 
Relacja absolwenta KSS Seweryna Walkowiaka [1974]. Archiwum Archidiecezjalne w Poznaniu, KSS, sygn. 26.

Sprawozdanie z Kursu dla wychowawców w zakładach zamkniętych w r. 1926/27. [1927]. APP, KSS, sygn. 5, k. 15.

\section{Źródła}

Drugi zjazd (1934). Biuletyn Absolwentów Studjum Spotecznego Katolickiej Szkoty Spotecznej w Poznaniu, 1, 1.

Katolicka Szkoła Społeczna w Poznaniu (1933). Nowy Kurier, 15 lipca, 10.

Kozłowski, E. (1922). Obecny stan katolickiej akcji społecznej w Polsce. Przewodnik Spoteczny, 33-40.

Kryński, A., Niedźwiecki. (1909). W. Stownik języka polskiego. T. 6. Warszawa: nakładem prenumeratorów i Kasy im. Mianowskiego.

Kurs dla wychowawczyń i wychowawców zakładów zamkniętych. (1926). Przewodnik Mitosierdzia, 8, 169-171.

Notatka prasowa dyrektora Katolickiej Szkoły Społecznej w Poznaniu ks. E. Kozłowskiego do redakcji czasopism. 13 grudnia 1927. APP, KSS, sygn. 1, k. 52 .

Rozporządzenie dotyczące utworzenia Katolickiej Szkoły Społecznej w Poznaniu. (1927). Miesięcznik Kościelny Archidiecezyj Gnieźnieńskiej i Poznańskiej, 6, 31-32.

Rozporządzenie Ministra Opieki Społecznej z dnia 12 września 1932 r. w sprawie zmiany w rozporządzeniu z dnia 10 października 1927 r. o kwalifikacjach kierowników zakładów opiekuńczych. Dz.U. 1932 nr 87, poz. 743.

Rozporządzenie Ministra Pracy i Opieki Społecznej z dnia 10 października 1927 r. o kwalifikacjach kierowników zakładów opiekuńczych. Dz.U. 1927 nr 100, poz. 866.

Sprawozdanie Katolickiej Szkoły Społecznej za rok 1928. (1930). Przewodnik Spoteczny, 1, 1-8.

Statut Katolickiej Szkoły Społecznej w Poznaniu. (1927). Miesięcznik Kościelny Archidiecezyj Gnieźnieńskiej i Poznańskiej, 6, 32-34.

Studjum Społeczne Katolickiej Szkoły Społecznej w Poznaniu. (1933). Wiadomości Archidiecezjalne Wileńskie, 15-16, 191.

Studjum Społeczne Katolickiej Szkoły Społecznej. (1932). Miesięcznik Kościelny Archidiecezyj Gnieźnieńskiej i Poznańskiej, 8, 71.

Ustawa z dnia 22 lutego 1937 r. o prywatnych szkołach wyższych. Dz.U. 1937 nr 13, poz. 89.

Wysocki, T. (2007). Struktura wyznaniowa studentów i absolwentów uczelni wyższych w roku akademickim 1937/1938. Przegląd Historyczno Oświatowy, $1-2,111-132$.

Wyższe Katolickie Studium Społeczne w Poznaniu. (a) (1939). Rozporządzenia Urzędowe Eomżyńskiej Kurii Diecezjalnej, 1 sierpnia, 90.

Wyższe Katolickie Studium Społeczne w Poznaniu. (b) (1939). Krzyż, 30 lipca, 247. 


\section{Opracowania}

Banaszak, M. (1974). Narodziny Katolickiej Szkoły Społecznej w Poznaniu. Chrześcijanin w Świecie, 4, 82-93.

Banaszak, M. (1983a). Dymek Walenty. W: E. Grzebień, Stownik polskich teologów katolickich (t. 5, s. 335-338). Warszawa: ATK.

Banaszak, M. (1983b). Jarosz Ludwik. W: E. Grzebień, Stownik polskich teologów katolickich (t. 5, s. 584-585). Warszawa: ATK.

Banaszak, M. (1983c). Schulz Józef Walenty Tadeusz. W: E. Grzebień, Stownik polskich teologów katolickich (t. 7, s. 91-92). Warszawa: ATK.

Banaszak, M. (1983d). Kozłowski Edward. W: E. Grzebień, Stownik polskich teologów katolickich (t. 5, s. 189-194). Warszawa: ATK.

Bender, R. (2000). Katolicka Szkoła Społeczna w Poznaniu. W: Encyklopedia katolicka (t. VIII, ł. 1088). Lublin: TN KUL.

Brenk, M., Chaczko, K., Pląsek, R. (2018). Organizacja pomocy spotecznej w Polsce $w$ latach 1918-2018. Podręcznik akademicki. Warszawa: Wydawnictwa Naukowe Scholar.

Gajewski, R. (1994). Dymek Walenty. W: R. Bender, Stownik biograficzny katolicyzmu spotecznego $w$ Polsce (t. 1, s. 122-123). Lublin: TN KUL.

Jachowski, J. (1970). Kozłowski Edward. W: Polski stownik biograficzny (t. XV, s. 5-6). Wrocław: Zkład Narodowy im. Ossolińskich.

Jarocki, S. (1964). Katolicka nauka spoteczna. Paryż: Societé d'Editions Internationales.

Jasiewicz, Z. (1988). Profesor Józef Burszta 1914-1987. Lud, 72, 6.

Kostkiewicz, J. (2013). Kierunki i koncepcje pedagogiki katolickiej w Polsce 19181939, Kraków: Oficyna Wydawnicza Impuls.

Kostkiewicz, J. (2015). Aksjologiczne orientacje w pedagogice katolickiej 20-lecia międzywojennego. W: K. Ablewicz, M. Cipár, D. Jagielska, J. Kostkiewicz (red.), Szkice z pedagogiki 20-lecia międzywojennego. Bratislava: Univerzita Komenského.

Kula, L. (1994). Kozłowski Edward. W: Stownik biograficzny katolicyzmu społecznego $w$ Polsce (t. II, s. 50). Lublin: TN KUL.

Leśniewska, E. (2009). Życie Wandy Szuman. W: B. Borowska-Beszta (red.), Wanda Szuman - pedagog i andragog specjalny - Szkice do portretu (s. 19-25). Radom: Wydawnictwo Naukowe Instytutu Technologii Eksploatacji - PIB.

Odziemkowski, J. (1994). Jarosz Ludwik. W: R. Bender, Stownik biograficzny katolicyzmu Spotecznego w Polsce (t. 1, s. 189). Lublin: TN KUL.

Piaszyk, M. (1979). Rola Katolickiej Szkoły Społecznej w Poznaniu w zawodowym dokształcaniu zakonnic. Roczniki Nauk Społecznych, VII, 85-104.

Samsel, A. (2003). Wychowanie przedszkolne w latach 1918-1939 (cz. II). Wychowanie $w$ Przedszkolu, 9, 518-522.

Wałęga, A. (2005). Życie i dziatalność Wandy Szuman (1890-1994). Toruń: Wydawnictwo Mado.

Wałęga, A. (2004). Środowisko rodzinne Wandy Szuman (1890-1994). Rocznik Toruński, 31, 137-165. 


\section{Catholic Social School of Poznań (1927-1939)}

\section{ABSTRACT}

The Catholic Social School of Poznań was one of the leading Polish didactic centers for social services in the interwar period. In the years 1927-1939 it conducted courses for and educated the staff of care and social institutions, especially those related to the Catholic Church. The priority of the school's activity was to organize, since the establishment of the institution in 1927, a two-year social work training course, later functioning under the name of the Higher Catholic Social College. In June 1937, the school obtained the state rights of the university and the name of the Higher Catholic Social College. The purpose of the article is to show selected aspects of the institution's functioning, related to its establishment and educational and education activities until 1939. For this purpose, the preserved source materials in the form of archives, articles published in the magazines of the Second Republic of Poland were analyzed, and few studies developed after 1945 were referred to.

Keywords: social school, social welfare, social services, Second Republic of Poland 